\title{
WHAT IS HAPPENING TO LUGHATUNĀ L-GAMİLA? RECENT MEDIA REPRESENTATIONS AND SOCIAL PRACTICE IN EGYPT
}

\author{
Gunvor Mejdell
}

\section{UNIVERSITY OF OSLO}

In one of his later papers (Carter 2006), Michael Carter traced the linguistic arguments and sources according to which the early grammarians based their description and rules of the Arabic language, and how with time this language came to be sanctified and given additional authority by identifying it as the language of the Qur ${ }^{\circ} \bar{a}$. Carter ends his article by addressing the challenges facing it, as the authority of grammar and of grammarians to control the language of the community fades away, and the 'language of the people', that is the vernacular varieties, takes over the domains of the classical 'Arabiyya. This article presents views and arguments found in Egyptian printed media over the past decade and relates them to earlier studies on the language debate. Finally, it discusses the extent to which these media representations reflect observed linguistic practice and social processes at work in the Egyptian language community.

The respective status and roles of al- ${ }^{c}$ Arabiyya and the spoken vernacular, ${ }^{\mathrm{c}} \bar{A}$ mmiyya, has been an issue throughout the modern history of Egypt and of other Arabic-speaking societies. Official language policies in Egypt, including those of the Language Academy (Magma ${ }^{c}$ al-Lugha al${ }^{c}$ Arabiyya) and educational authorities, have had the full functional restoration of al- ${ }^{c}$ Arabiyya as their proclaimed goal. With the spread of education in the $1950 \mathrm{~s}$ and $60 \mathrm{~s}$, optimism ran high that linguistic competence would improve among the people, to the extent that al${ }^{c}$ Arabiyya as the unified national language for the wider Arab nation would eventually replace the divisive regional and local tongues at all or most levels of communication. Voices calling for the recognition of the 'language of the people' and making it the basis of national standard languages have been relatively few and far between. The calls for tamșì allugha ('Egyptianizing the language') argued for a more liberal language policy and for narrowing the gap between the varieties, by allowing certain words and expressions from the everyday vernacular speech to be used in writing, and simplifying the grammatical rules of al- ${ }^{c}$ Arabiyya. However, apart from a few well-known proponents of making al- ${ }^{c} \bar{A} m m i y y a$ the national language, such as Tawfíq ${ }^{\mathrm{c}} \mathrm{Awwān}$, Lewis ${ }^{\mathrm{c}} \mathrm{Awad}$, and the 
radical Salāma Mūsā, who even supported the transition from Arabic to Roman script, the Egyptian language reformists never intended the codification and standardization of Egyptian Arabic (for accounts of the language debate in Egypt, see Diem 1974, Hamzaoui 1975 Gershoni and Jankowski 1986, Haeri 2003, Suleiman 2003, 2004). The use of this variety in literary works was mainly restricted to political poetry and drama, as well as dialogue in fictional prose, in order to promote realism of portrayal (cf. Somekh 1991, Mejdell 2006b).

While a certain troubled concern for the well-being of al- ${ }^{c}$ Arabiyya has long been expressed in the Egyptian language debate, a growing awareness and frustration among intellectuals, educators, and the cultural and religious establishment can be observed in the last ten to fifteen years, relating to what are perceived as serious threats and challenges to the present and future status of the language. The present paper will present samples of how this awareness and concern is reflected in Egyptian printed media in this period (based on a survey of newspaper articles/interviews/commentaries on linguistic issues collected from the CEDEJ archives in Cairo in 1997-8, 2001-2, and 2006-7). I shall relate the various views and attitudes expressed in these samples to representations of linguistic issues analysed in previous research, and finally discuss the extent to which they may be said to reflect and/or affect social practice, that is to say, linguistic behaviour.

Eisele's model of 'regimes of authority' in linguistic issues ${ }^{1}$

In some stimulating contributions, John Eisele outlines - in what is explicitly work in progress - a model for 'dealing with the culture-wide perception and representation of Arabic'. This seeks to integrate ideological positions and social relations in a theory of practice. It also approaches discourse on language as social constructs ('representations'), determined by sociocultural and individual experience and sociohistorical phenomena or 'practices' (Eisele 2003, 14). Eisele draws on Bourdieu's theoretical concept of 'habitus' - 'a set of dispositions which incline agents to act and react in certain ways [...] generate practices, perceptions and attitudes which are 'regular' without being consciously co-ordinated or governed by any "rule" (Bourdieu 1991, Introduction), or in other words, 'a cultural system of expectations giving rise to recognizable actions or practices' (Eisele 2003, 14). In this frame-

1 Drawing particularly on Eisele's work, 'Myth, Values, and Practice in the Representation of Arabic' in International Journal of the Sociology of Language 163 (2003), 43-59. 
work, Eisele operates with various 'regimes of authority' in discourse on language (including modern 'European' linguistics with its own sets of attitudes and expectations). ${ }^{2}$

In what he refers to as 'the dominant regime of authority' on Arabic linguistic issues, Eisele identifies four main themes or recurrent motifs ('cultural tropes'), which underlie the native tradition of written discourse, or narrative, of Arabic (ibid., 51):

unity: of the Arabic language and the cultural values it supports.

purity: the perfect state of Arabic, which must be guarded from contamination by other sources.

continuity: its invincibility, its depositing of the written tradition 'in which inheres the most highly valued features of the culture'.

competition: the state of conflict or competition with other languages, formerly Persian and Turkish, more recently French, and these days, above all, English.

Each motif, suggests Eisele, 'represents the valorization of specific cultural aspects of Arabic while it stigmatizes others' (Eisele 2002, 7). The obvious candidates for stigmatization, which 'disturb' the unity, purity and continuity of the language, are the vernacular varieties. They are viewed as representing linguistic (and sociocultural and political) diversity instead of unity; they threaten the purity of Arabic through their influence, or interference; they represent change and innovation, as against the continuity of the high language. Suleiman, referring to the conservative establishment as the 'language defenders', argues that underlying their grave concern with purity and correctness of al- ${ }^{c}$ Arabiyya and their deprecation of the spoken dialects, is the assumption that these varieties represent a state of decay and corruption that undermine the very value system of Arabic culture (Suleiman 2004, 74-80).

\section{Motifs in the current debate}

The valorization of the unity, purity, and continuity of al- ${ }^{c}$ Arabiyya, and the concern for the competition to which it is being exposed, are all strongly represented in recent media coverage of language issues. An additional (sub-)motif which is prominent in the data and which is related to the former motifs (which are also interconnected and overlap-

2 Tracing the changing views on grammar and language in the frame of European cultural history, John E. Joseph (1989) convincingly seeks to establish how 'both popular and scientific beliefs and attitudes about language status are consistent within the broader belief systems of which they are a part' (1989, 254). 
ping in discourse) is the uniqueness of Arabic: it is unique in beauty, morally unique in the sense of being a revealed, God-given language, ${ }^{3}$ and also unique as a historical entity (linking to continuity), as in:

The Arabic language has a status (makāna) which no other language in the world comes close to having. This language was able, throughout the ages, to stand firm (tașmud) in spite of the worst kind of trials (aswa al-mihan) it was exposed to. It was under attack from other languages in its own land, as it suffered from its people being alienated (tanakkur ahlihā) from expressing themselves in it. No other language, however vital and widespread it might be, could possibly withstand such events as the Arabic language did. (Al-Ahräm 6 June 1997).

Concerning the linguistic qualities of al-'Arabiyya, Al-Ahrām (30 Nov 2007) quotes the famous writer and critic al- ${ }^{c}$ Aqqād (d. 1964):

Applying the measures of linguistics to the Arabic language, we find there is no other language of greater perfection $\left({ }^{c} a w f \bar{a}\right)$ when it comes to vocabulary and grammar. We have the right to consider it the best of all languages even by just one measure, namely the human vocal apparatus: The Arabic language uses this apparatus to its utmost. ${ }^{4}$ (Al-Ahrām 30 November 2007).

Popular belief in the special qualities of one's national language is, of course, not specific to Arab culture. This is amply demonstrated in J. Fishman's book, In Praise of the Beloved Language. A Comparative View of Positive Ethnolinguistic Consciousness (1997) - a crosslanguage study of native language evaluation, where representations are lofty and high-flown, indeed. Even in a comparative perspective, however, Arabic discourse on language has a remarkably emotional touch, which also finds its way into academic writing on Arabic: lughatuna $\bar{l}$ jamīla, ${ }^{c}$ Arabiyyatuna hädhihi - its intimate ties with the Arab persona is expressed with affectionate use of pronouns as verbal manifestations of attachment and loyalty.

More as a curiosity, let me mention that even a critically minded soul as Edward Said lets himself be carried away by the unique qualities of the language:

3 Asked whether he considers Arabic a sacred language, professor $\mathrm{Ta}^{\mathrm{c}} \overline{\mathrm{i}} \mathrm{m} \overline{\mathrm{i}}$ comments that in the context of a religious text it is, but when used by a communist to attack the faith, it still is Arabic, but not sacred... (Al-Dustūr, 8 March 2006)

4 Eisele has analysed al- 'Aqqād's views on language in one of his contributions, and mentions this point. Its occurrence in 2007 shows the continuity of the notion! 
[Classical Arabic] emerges as a sonorous, carefully modulated, heightened and extraordinarily inflected instrument capable of great, often (but not always) formulaic eloquence. Properly used, it is unmatched for precision of expression and for the amazing way in which individual letters within a word (but especially at endings) are varied to say quite distinct and different things'. [C]lassical Arabic, its rules, inflections, syntactical modes, and overpoweringly beautiful richness seems to exist in a sort of abiding simultaneity of existence that is quite unlike any other linguistic state that I know of' ('Living in Arabic' posthumously printed in Al-Ahrām Weekly 12 February 2004).

Defending the beautiful language from external threat

In recent years, and most notably in Egypt, concern has grown into an alarming awareness that the beautiful language is in deep crisis, with media headlines typically calling for people to stand up for 'this language which is being exposed to evil attacks from within and from without' (hädhihi al-lugha allatī tatacarraḍ li-hajma sharisa min al-dākhil wa-l-khārij).

The external threat is perceived as coming from the pressures of globalisation ( ${ }^{c}$ awlama) imposing Western political, economic and cultural hegemony. The notion of conflict, in the sense of 'competition', is coached in strongly marked evaluative terms (rape, evil forces etc.). 'Our beautiful language is being raped in commercials, on shop facades, in the streets, in schools and universities', complains the Egyptian opposition paper, Al-Shac $b$ (1 November 1996) ${ }^{5}$, and likens the present situation to the darkest days of the British occupation. The centrality of al- ${ }^{c}$ Arabiyya for the Arab construction of national identity is repeatedly evoked, e.g. 'We must cling to al- ${ }^{c}$ Arabiyya to safeguard our identity in the face of the pressures of globalization' reads a typical headline in Al-Ahrām (27 June 1997). To the writer Muhammad Galāl, interviewed in Sawt alAzhar (21 July 2006), al- ${ }^{c}$ Arabiyya is 'the daughter of the people [...] whose position will be strong or weak depending on her family [...] In times of hardship we cannot expect too much of her'. Nowadays, however, there is a genuine awakening in the Arab world, claims Galāl, which is 'ready to stand against the evil forces which do not wish well for the Arab nation, and want it to be even more fractured than it is' (ibid.) But the Arab peoples have learned to fight for their values, he says, and the real value of the nation is the Arabic language, which will remain strong, because it is the language of the Qur ${ }^{\circ} \bar{n}$, which protects its honour (sharaf). There must be a common awareness that the honour

5 Here taken from the English language weekly Al-Ahrām weekly 21 October 1999. 
of this nation is the Arabic language, and that the nation must stand united to protect the honour of this Arabic language/daughter (ibid.).

\section{The internal challenges}

Equally important and damaging, if not more, are the effects of internal neglect:

'The trials of the Arabic language began with the decline of nationalism', claims a member of the parliamentary Cultural Committee to $A l-U s b \bar{u}^{c}$ (11 May 1998). The isolation and marginality of the Language Academy is frequently addressed, as in the article found on the cultural pages of Al-Wafd newspaper (27 February 2001): There is no continuity between generations, as almost all members are of old age, and nobody heeds their advice, anyway, complains dr. Ḥāmid Țāhir. 'Its current rigidity is turning it into a mausoleum' says dr. Șalāḥ Qanșuwwa, while dr. al-Tāhir Makkī criticizes the Academy for neglecting the media, thereby staying aloof of the public (ibid). 'Society blames it [the Academy], while nobody is interested in its recommendations'. (Al-Jumhüriyya 11 May 2001).

'The Arabs have treated the Arabic language with contempt, and their cultural weakness has doomed its future', denounces al-Dustür, and continues: 'the foreign languages are strengthened thanks to the private schools and to the embassies who care for their national languages. (al-Dustūr, 8 March 2006).

'The Arabic language is being fought by its own people, especially in Egypt', says Dr Muștafāa al-Shak ${ }^{\mathrm{c}}$ a of the Council for Islamic Research to al-Ahräm. 'If the child does not know the language of his family/nation $(a h l)$, he will grow up ignorant. We are not against teaching other languages, but we demand that we only learn them after we know and understand the Arabic language thoroughly' (Al-Ahrām 30 November 2007). Also a recurrent blow to national pride is the claim that ' $[w]$ hile the Jews have revived their dead language, we are killing our living language' ( $A l-U s b \bar{u}^{c} 11$ May 1998).

The explosion, in recent years, in the number of private schools (madāris al-lughāt), where all subjects are taught in a foreign language (mostly English), and Arabic constitutes a minor discipline, is commonly mentioned as having an alarming effect on the competence in Arabic of young people of the middle class: ${ }^{6}$ 'The new generation does not know the rules of grammar, but they do know 'Very good'! (Rushdī Ta ${ }^{c} \overline{1} m \overline{1}$ interviewed in Al-Dustūr 8 March 2006). He illustrates his point with the story of a student in college who wanted to offer her professor a present,

6 Apparently, most families who can afford it - and many sacrifice a lot to be able to-have their children go to these schools, because of the wretched condition of government schools, including those who worry about the decline of Arabic due to the proliferation of private language schools. 
something he politely refused. She looked at him in bewilderment and said (in 'Ámmiyya): 'But why, doctor - even the Prophet accepted cadeaux'. The daughter of a friend was asked by her father what she had learned in the religion class at school that day: 'the teacher told us about our Lord Muhammad, that he went to Abū Bakr al-Ṣaddīq and asked him to accompany him on the hijra to Medina. - Okey, yā Muhammad, said Abū Bakr'.

The effect of this neglect, it is claimed, leads to al- ${ }^{c}$ Arabiyya losing interest and prestige in society:

There is a rush to use foreign languages, and it is considered a shame to speak them [foreign languages] incorrectly - while the person who uses al- ${ }^{c}$ Arabiyya is made fun of, and one takes pride in not pronouncing its sounds and expressions correctly' (Al-Ahräm 13 June 97).

The ever-increasing spread of 'Ámmiyya, young people's 'strange talk', as well as the influx of foreign languages into al- ${ }^{c}$ Arabiyya, has even affected the well educated, "who seem to think that adding foreign terminology to their speech is a new way to earn people's respect and to appear distinguished' (Sawt al-Azhar, 1 September 2006).

The decline in educational standards and the influence of ${ }^{\mathrm{c}} \overline{\mathrm{A}} \mathrm{mmiyya}$

The general crisis of education (azmat al-nizām al-tac lìm $\bar{\imath}$ ) as part of the crisis in Egyptian society is commonly mentioned as one of the main reasons for the slide in language competence. More specifically, low standards of teaching Arabic grammar (azmat al-dars al-nahw $\vec{l}$ ), with the conservatism and rigidity of the Arabic teaching tradition is also frequently blamed. The lack of competence of Arabic teachers is considered both a result of and a reason for their low standing in society. The Arabic teacher has become an object of ridicule (Al-Dustūr).

'Al- ${ }^{c} \overline{A m m i y y a}$ threatens to wipe out the Arabs' reads a headline in the literary weekly Akhbār al-Adab (19 March 2006), and follows up:

A national obligation (wājib qawmi wa-watani $)$ calls upon us to stand up against this conspiracy. [T] here is no difference of opinion with regard to the existence of a far-reaching struggle between ${ }^{~} \bar{A} m m i y y a$ and $F u s h \bar{a}$ in various domains of everyday life. We can observe it in our schools, universities and the media - arenas where we should protect and defend al-Fușha - because 'Ámmiyya is an illness which has become more serious among the Arabs'.

The stigmatization of ${ }^{c} \overline{A m m i y y a}$, however, appears to be less prominent in the recent media debate than what has been observed and reported in earlier years. The discourse in general is less polarizing, and ' $\bar{A}$ mmiyya is more often presented as a natural fact of any language - sometimes 
normalized by referring to French argot (which is not quite appropriate). A typical non-antagonizing example is represented by $\operatorname{Dr}^{\mathrm{c}} \mathrm{Abd}$ al- ${ }^{\mathrm{c}} \overline{\mathrm{A}} \mathrm{t} \overline{1}$ Kaywān from the Faculty of Education, Fayyūm branch of Cairo University, who writes the following about the relationship of ${ }^{c} \bar{A} m m i y y a$ to Fușhā:

While ${ }^{c} \overline{A m m m i y y a}$ is the core of speech (kalām) in the language of everyday conversation, it should be noted that ${ }^{c} \bar{A} m m i y y a$ is derived from Fuṣh $\bar{a}$ in both its uttered and written forms, with some simple transformations that imposed itself on many words. This is not said in defence of ${ }^{c} \bar{A} m m i y y a$ or belittling of Fuṣha, nor [can it be said that] ${ }^{C} \bar{A} m m i y y a$ is evidence of the weakness of the Arabic language or its lack of significance among people. That will never happen, because, while we speak in 'Āmmiyya, we write in Fușhā. This has been characteristic of the Arabic language since its early beginnings' (Al-Ahrām 27 Nov 2001).

A new source of corruption: lughat al-shabāb

Whereas ${ }^{c} \bar{A} m m i y y a$, the spoken language of the people, is mostly absolved for its corrupting influence, a common topic in earlier years, the attention increasingly is focused on really 'bad' language: 'our Arabic language has drowned in the sea of street/vulgar language. Commercials, television series and songs all work to spread such speech' says a headline (Al-Akhbār 23 August 2002). And in the last few years a new source of corruption is captured by the commentators: 'the young destroy our beautiful language!' (al-shabāb yudammir lughatanā al-gamīla) cries a headline in Al-Masa $\bar{a}^{\top}$ iyya (8 August 2006) - referring to the uses of shortened and mixed codes on SMS texts and chat, as well as a new jargon ${ }^{7}$ spreading among urban youth: "they create a new language in their conversations on the net and the mobile, they have exchanged words of the Arabic language with letters and numbers written in Latin script'. But conservative professor, ${ }^{\mathrm{c}} \mathrm{Abd}$ al-Șabbūr Shāhīn, of Dār al- ${ }^{\mathrm{c}}$ Ulūm College takes it calmly: 'Al-lugha al- ${ }^{c}$ Arabiyya al-Fuṣhā will not be influenced by any revolt or violation, whereas the dialects change in successive generations'. For some, the linguistic decline reflects a general decline in behaviour among the new generation, a lack of respect for their Arab culture and tradition. For others, more sympathetic to the situation of young people, it is a way to express feelings in shorthand (ikhtizäl almash $\bar{a}^{c}$ ir) in a tough world with a broadened social gap between the elite from the foreign language schools and the children of modest families from government schools. According to psychologist Shihāta Zayyād, 'to invent a new language is something normal, al-lugha al- ${ }^{c} \bar{A} m m i y y a$

7 A guide to young people's slang (al-rawshana) can be found on http://fowatown.jeeran.com/1.html (accessed 11 September 2008). 
absorbs all that is new'. He stresses that this is not a psychological illness, but rather, 'a willed and conscious denial (rafd) from the young generation of what is happening around them in society, and which they in the present situation have no possibility to change [...] the individual's act of protest against oppression, trying by all means to escape his uneasiness and to create a code of mutual understanding among his peers, who just like him suffer from unemployment and the economic situation in the country' (ibid.).

\section{Promoting the status of ${ }^{\mathrm{c}} \overline{\mathrm{A}} \mathrm{mmiyya}$}

Discourse which openly challenges the 'dominant regime of authority' and promotes the status of ${ }^{c} \bar{A}$ mmiyya, is still rarely found in the media. In the roundtable organized and reported by Al-Ahrām (20 June 1997), Fatḥ̄ Imbābī asks: 'what is a standard language (lugha mic yāriyya)' and questions the functionality of Classical Arabic (al- ${ }^{c}$ Arabiyya alklāsikiyya). He suggests that the grammatical structures be 'liberated' and 'revised on the basis of the language used by the Egyptians, the Egyptian language' ${ }^{8}$ Here he is abruptly interrupted by the moderator: 'I do not want to go on with this. What you are saying implies that there is an Egyptian nation (wattan) and an Egyptian language. This is not acceptable. We are part of an Arab nation (umma) and we speak the Arabic language. This language is basic in upholding a national identity (hüwiyya qawmiyya)'.

Apart from this, open support for ${ }^{c} \bar{A} m m i y y a$ was expressed in two recent articles, both in the weekly al-Qähira. In the first, from 11 September 2007, the case for the language of the people is coached in an unmistakably radical discourse as in the headlines: 'diglossia is a strong expression of class division in the Arab societies' (al-izdiwāj al-lughaw bayna Fuṣhā wa- ${ }^{c} \overline{A m m i y y a}$ yuc abbir bi-quwwa ${ }^{c}$ an al-inqisām al-țabaqū fi-l-mujtamac āt al- ${ }^{c}$ Arabiyya), and '[t]ime has come for the oppressed popular culture/cultural expressions (al-thaqafāt al-shacbiyya almazlüma) to start moving'. The text continues:

The languages (lughāt) which were oppressed (qumicat) so that they should not carry out the act of writing, such as the Egyptian vernacular ( $\left.{ }^{C} \bar{A} m m i y y a\right)$, found refuge in the oral arts. The oppression (zulm) which is linked to popular culture goes back to that evil dichotomy which divides humanity into masters and slaves.

Then the argument is taken one step further:

\footnotetext{
8 For more on Fatḥ̄ Imbābī’s position as well as some other radical contributions, cf. Mejdell 2006, 23-4.
} 
We can understand how Egypt as well as Tunisia, both anthropologically distinguished from the the Semitic Arabs, came to be culturally Arab, at least relatively, due to the long linguistic and religious contacts, and finally also politically, standing together in one camp (for a certain period), namely in the struggle against modern and contemporary Western colonialism. The central issue in this is the following: is it possible to consider the Arabic language (allugha al- ${ }^{c}$ Arabiyya), which was imposed on Egypt under the reign of ${ }^{c} \mathrm{Abd}$ alMalik ibn Marwān in the hijra year 87 and which was officially elected for Tunisia in 1974 as the first language of these two peoples - the mother tonguelisān al- ${ }^{\circ}$ umm? Certainly not.

The mother tongue issue is raised more acutely in the next article, signed Fathị Sayyid Farag, under the headline: 'The Egyptians are in constant trouble because they learn a language which is not their national language (laysat lughatahum al-qawmiyya)' (30 October 2007). The journalist emphatically refers to al- ${ }^{c}$ Arabiyya as not being al-lugha al- ${ }^{\circ} u m m$ or lughat al-umm, thus challenging the established notion of al'Arabiyya as 'mother tongue' In this, the writer is in line with modern Western practice, where the notion 'mother tongue' is applied to the primary and psychologically most entrenched linguistic variety of the individual - and thus not appropriately applied to al- ${ }^{c}$ Arabiyya, being a secondary variety. (On the other hand, it might in fact make sense to call al- 'Arabiyya a 'national language', especially as the use of qawmiyya normally refers to Pan-Arab nationalism.)

In this article, furthermore, we encounter the strong and rather unusual (in the Egyptian context) claim that the Egyptian ${ }^{c} \bar{A}$ mmiyya is an independent language with no connection to al- ${ }^{c}$ Arabiyya (wa-lakinnaha $\mathrm{fi}_{\mathbf{l}-l-}$ haqīqa lugha mustaqilla la ' 'alāqa lahā bi-l-lugha al-'Arabiyya'), only interspersed with some Arabic words. The article cites Bayūmī Qindīl to the effect that modern Egyptian has Hamitic origin (dhät aṣl ḥam $\bar{a}$ ), being a continuation of the forms of the ancient Egyptian languages (imtidād li-hurüf al-lughāt al-mișriyya al-qadìma), thus it is not Semitic and Phoenician like al- ${ }^{c}$ Arabiyya (here) is said to have. Among the many specific features of modern Egyptian, he mentions that the Egyptian language 'has made an enormous step' by dropping declension of the relative marker. It also hails the Egyptian language for having 'relieved itself of heavy consonants ( hurüf thaqüla) which need muscular efforts in producing them, passing the lower back parts of the vocal organ' (ibid.) Here, the writer is actually referring to loss of medial hamza and monophthongization of diphthongs. While the features mentioned in the article as specific to Egyptian (as opposed to al- ${ }^{c}$ Arabiyya) are common to most modern Arabic dialects, and do not reflect Hamitic origin, 
the thrust of the article is of course to emphasize the distance between the varieties. The article ends with denouncing those who defend the present 'diglossic' situation and neglect its harmful effects.

\section{Urgent appeal}

Over the last few years, the texts in support of preserving the beautiful language convey, if anything, an even more desperate urgency, together with a sense of disillusionment, as this interview with Ramaḍān Abū Ismā̄ $\overline{1}$ illustrates:

There have been many initiatives and declarations the last years from various official and non-official institutions calling for raising Arab awareness/consciousness concerning the situation of the Arabic language - this language which God honoured by making it the language of the Qur ān. Some years ago the Lisān al- ${ }^{c}$ Arab Society [funded by ALESCO] announced that the year 2004 should be the year of celebration of the language and of finding ways to raise its status and meet the numerous challenges facing it, internal as well as external. And there were, in fact, organized seminars and conferences about this, but to no avail' (Sawt al- ${ }^{\circ}$ Azhar 21 July 2006).

He goes on to say that the year 2006 was similarly proclaimed 'year of al- 'Arabiyya': again seminars and conferences are organized, statements and recommendations are issued - and thrown into the 'basket of neglect'. The decision-makers (așhāb al-qarār), pay no attention to them, "while the other nations are about to achieve their fundamental goal: a gap separating our young generation from its Qur ${ }^{\top} \bar{n}$ and its cultural heritage'.

Akhbār al-adab (19 March 2006) quotes from an article by Islamist writer Fahmī Huwaydī deploring the current situation:

The degree of neglect which has befallen the Arabic language in the Arab world is a catastrophe. The first year students of al-Azhar are obliged to learn French, while France prohibits the teaching of any foreign language in this early phase.

Acknowledging the alarming proportions (tafāqum) of the problem he writes: 'Time has come to raise our voices loud to call for people to get to know the language (lisānn) of the Arabs'. For several years, he says, he has championed the case of the language of the Qur ${ }^{\supset} \bar{n}$ in the Islamic states in Asia and Africa [...] 'but with bitterness we must admit that it has been defeated in its own countries'. He points to Mauritania, which he claims has ceased teaching al- ${ }^{c}$ Arabiyya in its schools, though the country used to be one of the strongholds of the language. He deplores the situation in North Africa, where political leaders are more comfortable in French than in Arabic. In the Gulf area, Urdu establishes itself as a second language, while English has becomes the language of education, and Arabic is becoming marginalized. Finally, concerning Egypt, 
he claims that, "it is indeed very sad that in the largest Arab country the learning of foreign languages has become a national goal and that in many milieus gibberish language (al-rațāna) is totally acceptable'.

The new interest in the West in recent years for learning Arabic gives rise to bitter irony, as in these headlines: 'The language of al-Qur'ān - its enemies are learning it, while its people is neglecting it', and: 'We, sons of the Arabic language, are killing this language' (Al-Ahrām 30 November 2007). In his commentary 'Thanks to terrorism' (shukran lil- ${ }^{\circ} i r h a \bar{b}$ ) Egyptian author Yūsuf al-Qa ${ }^{c} \overline{1} \bar{d}$ observes the proliferation in Cairo of courses and schools teaching Arabic to foreigners; he sarcastically dismisses that the impetus for this interest would be respect for Arab people or culture, or even the strength of the area's political and economic weight in the world. It is 'thanks to the terrorist attacks, that the rest of world flock to learn the language of the enemy, and through the language know their ways of thinking, as in the slogan: Know your enemy!' Ironically, writes al- $\mathrm{Qa}^{\mathrm{c}} \overline{\mathrm{i}} \mathrm{d}$, this upsurge of interest in al- ${ }^{c}$ Arabiyya from outsiders 'coincides with a dramatic decline for the 'Arabiyya from its own people and speakers - to the extent that there is a situation of alienation concerning the language among its people' (Al-Mușawwar 31 March 2006).

I give the last word to the president of the Language Academy, Maḥmūd Hâfiz, who deeply deplores 'the people's insistence on using ${ }^{c} \overline{A m m i y y a}$ [which] hastens the process of deterioration and decline [of al-'Arabiyya]' (Al-Ahrām 30 November 2007).

\section{Representations of language and social practice}

What is reflected in these representations is a sense of total collapse of the status and functions of al- ${ }^{c}$ Arabiyya. While representations do not necessarily reflect the full truth of social reality (or practice), the ideologies, perceptions, and attitudes they reflect are part of a process and contribute to shaping reality. They are a sign that educated Egyptians are aware of an approaching doomsday for the beautiful language - and that they feel they are not able to avert it. A minority welcomes the current development and sees it as an opportunity for the language and culture of the people to gain status and recognition. Most people - especially among the new generation (some estimates claim that some fifty per cent of the population are under the age of twenty-four) - apparently do not care very much. Some may see their future interest linked to competence in English rather than al- ${ }^{c}$ Arabiyya, while ${ }^{c} \overline{A m m i y y a}$ takes care of the functions of their everyday lives. We may assume that for most young Egyptians these days their lives are overshadowed by crises looming larger 
and more acutely than issues of language and identity.

Why do Egyptians 'insist on using 'Ámmiyya' when they should use al- ${ }^{c}$ Arabiyya according to the dominant language authority? Modern sociolinguistics and social network theory hold that language practice and linguistic change in a language community is overwhelmingly related to social status of speakers and the prestige of actual, living role models. In her influential work on language norms and practice, Renate Bartsch claims that:

[N]orms [of language] are the constellations in social reality that create, delimit and secure the notions of correctness. These norms consist of relationships between people, in which it is determined what the models or standards which have to be followed are, who have to follow which models, who provide models, and who enforces, if necessary, adherence to the models (Bartsch 1987, 70).

It is not necessarily the norm with the highest official prestige, as al${ }^{c}$ Arabiyya unquestionably still has, which serves as models for people. Interesting evidence for the existence of competing forms of prestige, i.e. competing norms for linguistic practice, and in an Arabic setting, is provided by Ibrahim (1986): local Jordanian women in a village setting were observed in the process of linguistic change; a change not in direction of the standard language, however, but towards linguistic norms set by urban women, even when it involved a change away from features that were shared by their local dialect and al- ${ }^{c}$ Arabiyya. The social status of urban women, with their more modern and sophisticated ways in the eyes of the female villagers, proved stronger than the status of whoever were the practitioners of al- ${ }^{c}$ Arabiyya, e.g. school teachers and imams (and naturally of the locals), and - so the argument goes - made them role models for imitation.

The role models for the early grammarians are reported to be the native speakers of the desert, possibly only some of them, 'on whose language use one could rely': 'arabiyyan mawthūqan bi- 'Arabiyyatihi, sami ${ }^{c} n \bar{a}$ man yüthaqu bi- ${ }^{c}$ arabiyyatihi yaqūlu (Sībawaihi, in Levin 1994, 207), or 'whose Arabic is acceptable': fi lughat man turtada 'Arabiyyatuhu (ibid., 209). The medieval cultural elite, including the grammarians, may be assumed to have been models of correct usage among themselves and to their students. As Carter $(1983,66)$ suggests, 'as the inevitable preliminary to all educated discourse, a knowledge of grammar was usually taken for granted'. Carter here, twenty-five years ago, cites J.-P. Charney as to the functional role of language 'as a system of reference to certain values [...] permitting each individual to 'test', to verify and affirm his belonging to the group' (ibid.). 
In contemporary Egyptian society, there are hardly any influential models motivating the oral use of $a l^{c}$ Arabiyya. Popular culture, movies and songs are since long performed in ${ }^{c} \overline{A m m i y y a}$. The most popular Islamic preacher among young and old in Egypt, is ${ }^{\mathrm{c}} \mathrm{Amr}$ Khālid, whose live and recorded performances are mainly in ${ }^{c} \bar{A} m m i y y a$, interspersed with a few Quranic verses. And for those who aspire for a better life economically, their role models will be businessmen and entertainers, who have little regard for the beautiful language.

My own research (Mejdell 2006) has demonstrated that even highly educated Egyptian academics with a high level of linguistic competence, when talking to an audience on cultural and social matters, prefer strategies of code-switching and mixing of varieties, to regular standard Arabic, not only for reasons of ease, but also because a less formal way of speaking reflects on them as modern and liberal-minded, but still cultivated people, and in addition makes communication with the audience more direct.

As elsewhere in the world, the domains of traditional 'high' culture and literature are under some pressure, and 'lighter' genres are entering into competition. The Egyptian linguist, Madiha Doss, gives evidence of how ${ }^{C} \bar{A} m m i y y a$ is increasingly used-in some works exclusively-in both literary and non-literary writing, (Doss 2004). The younger generation employ the vernacular (and other languages) in blogs and other web productions. ${ }^{9}$ And in Autumn of 2006, the Egyptian satellite channel OTV challenged another bastion of al- ${ }^{c}$ Arabiyya, when it started broadcasting its news bulletins in ${ }^{c} \bar{A}$ mmiyya. ${ }^{10}$

Not only in Egypt, but in many regions of the Arab world, changes apparently are under way. A competent Western observer recently reports:

During my visits to Morocco in the last few years I have noticed a development in this country that has interested me for many years: there is a growing use of the Moroccan Arabic dialect (the local low variety) for written purposes. My visits to Syria, Lebanon and Egypt were intended to compare the situation in these countries with the situation in Morocco. And indeed, I noticed that a simi-

9 A pilot survey of 'online communication' in Cairo (Warschauer et al. 2007), showed that English and Egyptian Arabic (roman, but also arabic script) were by far most commonly used in email and online chat. The use of romanized Egyptian Arabic is rightly said to represent 'a major expansion of its written use'.

10 A most interesting study of this channel, 'which explicitly addresses a young audience', and of the processes behind its news bulletin is Doss (forthcoming). 
lar development is taking place in Lebanon, that in Syria this development seems to be at an initial stage, and that Egypt is far ahead of the other countries mentioned (Professor Jan Hoogland, NVIC Newsletter, November 2008).

As for the Maghrib, the research of Dominique Caubet (INALCO, Paris) documents the flourishing of young - and not so young - artists, musicians and playwrights using the vernacular as medium, In Morocco, a weekly magazine, Khbar Bladna, appeared in 2002 using the dārija (the colloquial), written in Arabic script. Its 6,000 copies were distributed free of charge across Morocco. In 2005, in the Rabat/Salé area, another journal in the colloquial, $\mathrm{Al}$-Amal, was launched, this time regional in scope and content, and with social welfare and objectives. Supported by the director of the regional Institute for Information and Communication, Al-Amal apparently became an instant success, with demands for similar initiatives elsewhere. (www.jeunemaroc.com, published 13 June 2006, accessed 18 December 2008).

Khbar Bladna later expanded to become a publishing house and set up a new literary price, Bladi Bladna, in order to encourage dārija prose literature. It was the writer Youssouf Amine Elalamy who reportedly published the first novel in this variety, in February 2006 (ibid.)

There is no doubt that al- ${ }^{c}$ Arabiyya holds the fort as the absolutely dominant variety for writing Arabic, so these vernacular trends are at least not yet in a position to dethrone the beautiful language. From various sources one can observe a certain optimism concerning a revitalisation of al- ${ }^{c}$ Arabiyya as a spoken medium - and thus a strengthened linguistic unification of the Arab peoples, through the new satellite channels broadcasting all over the Arab world. Most observers assume, however, that the language form of these channels represent some kind of standard variety. My impression is that these new media - beyond the control of state censorship, riqāba, also represent a freedom of expression beyond the control of the linguistic riqa āba. A web comment on the Arabic satellite news coverage of the Iraq invasion, included the following remark:

The quick war tempo and difficulty of prior preparation revealed incredible weakness in Arabic language mastery on the part of correspondents, some TV announcers and presenters. The best was Al-Jazeera, followed by Abu Dhabi, in terms of verbal and structural mastery of language. This served also to reveal the poor language of Gulf officials, who made basic mistakes in grammar (the Saudi foreign minister persisted on screen in making the word harb ('war') masculine rather than feminine. ${ }^{11}$

11 Abbas al-Tonsi, http://www.tbsjournal.com/Archives/Spring03/tonsi.html 
If these well-established and well-funded channels have problems with linguistic correctness, what can one expect from channels with lesser resources and perhaps less access to highly educated professionals and dignitaries? This may represent a challenge to the beautiful language but only to its strict unity and perfect purity. It promises vitality - if only one accepts the range of variability which its speakers and writers already make use of. In this final comment, I reveal my own preferences, of course, which (as Eisele reminds us) is part of a predominant, but not exclusive, European regime which values vitality, variation and change over unity, purity and continuity.

\section{BIBLIOGRAPHY}

Bartsch, Renate. 1987. Norms of Language. Theoretical and Practical Aspects. London/New York: Longman.

Bourdieu, Pierre. 1991. Language and Symbolic Power. Cambridge: Polity Press.

Carter, Michael G. 1983. 'Language Control as People Control in Medieval Islam. The Aims of the Grammarians in their Cultural Context' in Al-Abhäth 31, 65-84.

Carter, Michael G. 2006. 'The Qur'ān and the Authority of Arab-Islamic Linguistics' in Edzard, Lutz and Jan Retsö (eds.), Current Issues in the Analysis of Semitic Grammar and Lexicon II, Wiesbaden: Harrassowitz Verlag, 11-22.

De Ruiter, Jan Jaap. 2006. Les Jeunes marocains et leurs langues. Paris: L'Harmattan.

Diem, Werner. 1974. Hochsprache und Dialekt im Arabischen (Abhandlungen für die Kunde des Morgenlandes XLI,1) Wiesbaden: Franz Steiner GMBH.

Doss, Madiha. 2006. 'Cultural Dynamics and Linguistic Practice in Contemporary Egypt' in Abdelrahman, Maha et al. (eds.), Cultural Dynamics in Contemporary Egypt. Cairo Papers in Social Science 27/1 and 2, 51-68.

Doss, Madiha. (forthcoming). Hầl id-dunya: An Arabic News Bulletin in ${ }^{c} \bar{A}$ mmiyya.

Eisele, John. 2002. 'Approaching Diglossia: Authorities, Values, and Representations' in Aleya Rouchdy (ed.), Language Contact and Language Conflict in Arabic. Variations on a Sociolinguistic Theme. London/New York: Routledge, 3-23.

Eisele, John. 2003. 'Myth, Values, and Practice in the Representation of Arabic' in International Journal of the Sociology of Language 163, 
$43-59$

Gershoni, Israel and James P. Jankowski. 1986. Egypt, Islam, and the Arabs: The Search for Egyptian Nationhood, 1900-1930. New York/Oxford: Oxford University Press.

Haeri, Niloofar. 2003. Sacred Language, Ordinary People. New York: Palgrave.

Hamzaoui, Rached. 1975. L'Académie de lange arabe du Caire. Histoire et Oeuvre. Tunis: Publications de l'Université de Tunis.

Holes, Clive 1987. Language Variation and Change in a Modernising Arab State: the Case of Bahrain. London: Kegan Paul International.

Ibrahim, Muhammad H. 1986. 'Standard and Prestige Language: A Problem in Arabic Sociolinguistics' in Anthropological Linguistics 28/1, 115-26.

John E. Joseph. 1989. 'Popular and Scientific Beliefs about Language Status: An Historical Sketch' in Ulrich Ammon (ed.), Status and Function of Languages and Language Varieties. Berlin/New York: Walter de Gruyter, 243-55.

Levin, Aryeh. 1994. 'Sībawaihi's Attitude to the Spoken Language' in Jerusalem Studies in Arabic and Islam 17, 204-43.

Mejdell, Gunvor. 2006. Mixed Styles in Spoken Arabic in Egypt. Leiden/Boston: Brill.

Mejdell, Gunvor. 2006b. 'The Use of Colloquial in Modern Egyptian Literature - a Survey', in Edzard, Lutz and Jan Retsö (eds.), Current issues in the Analysis of Semitic Grammar and Lexicon II, Wiesbaden: Harrassowitz Verlag, 195-213.

Suleiman, Yasir. 2003. The Arabic Language and National Identity. Washington D.C.: Georgetown University Press.

Suleiman, Yasir. 2004. A War of Words: Language and Conflict in the Middle East. Cambridge: Cambridge University Press.

Warschauer, M., El Said, G. R. and Zohry, A. 2007. 'Language Choice Online: Globalization and Identity Online' in Danet, B. and S. C. Herring (eds.) 2007, The Multilingual Internet: Language, Internet, and Communication Online, New York: Oxford University Press, 303-318. 